\title{
Halal Industry in Indonesia: The Role of Sharia Financial Institutions in Driving Industrial and Halal Ecosystem
}

\author{
M. Aulia Rachman ${ }^{1} \&$ Syamsuddin ${ }^{2}$
}

\begin{abstract}
Halal market has emerged as a sector of new development and creating market potential in the global economy. Sharia Financial Institutions (SFI) has an important role as an intermediation between unit deficits and surpluses in the economy with sharia principles. As the development of halal products and industries make SFI have an important role in encouraging the growth, literacy and potential of the halal industry. This paper presents the ideas and roles of SFI in encouraging the potential of halal industry in Indonesia. Using qualitative descriptive approach, this paper finds out that there is still unbalance between the availability of products, demands, markets and the structure of halal industrial institutions. The halal certification efforts are still focused on food, medicines, and sharia financial institutions. Products related to tourism industries and information media remain untouched.
\end{abstract}

Keywords: Islamic Financial Institutions, Halal Industry, Halal Ecosystem

\begin{abstract}
Abstrak. Pasar produk halal muncul sebagai sektor pembangunan baru dan telah menciptakan pasar potensial dalam ekonomi global. Lembaga Keuangan Syariah (LKS) memiliki peranan penting untuk menjembatani antara unit defist dan surplus dalam praktek ekonomi syariah. Artikel ini bertujuan untuk memberikan gambaran mengenai potensi, prospek dan literasi terkait dengan industri halal di Indonesia; dan peran LKS dalam mendorong tumbuhnya ekosistem dan industri halal. Dengan menggunakan metode kualitatif deskriptif, kajian ini menemukan bahwa potensi yang besar pada industri halal masih perlu dikembangkan dan didukung oleh pemangku kepentingan terkait. Masih ada ketidakseimbangan antara produk, permintaan, pasar dan stuktur kelembagaan dalam industri halal. Terkait dengan jaminan halal, upaya sertifikasi halal masih difokuskan pada produk-produk makanan, obatobatan dan LKS, sementara produk terkait dengan industri pariwisata dan media informasi masih belum tersentuh.
\end{abstract}

Kata kunci: Lembaga Keuangan Syariah, Industri Halal, Ekosistem Halal 


\section{Introduction}

The halal global market in recent years has experienced rapid growth. The halal industry consists of businesses, which their operations are in accordance with sharia principles. Regardless of the association of the halal word with Islam, the halal economy ultimately benefits the entire global community (WIFM, 2014). The global community has been increasingly aware that the use of products from the halal industry has proven to be safer and more convincing in terms of health and other technical aspects. The development of global transaction value of the halal industry in 2015 reached 1.9 trillion dollars in all sectors. The total Islamic financial assets amounted to 2.0 trillion dollars in the same year (Thomson Reuther, 2016).

Figure 1. The Transaction Value of Global Halal Industry 2015

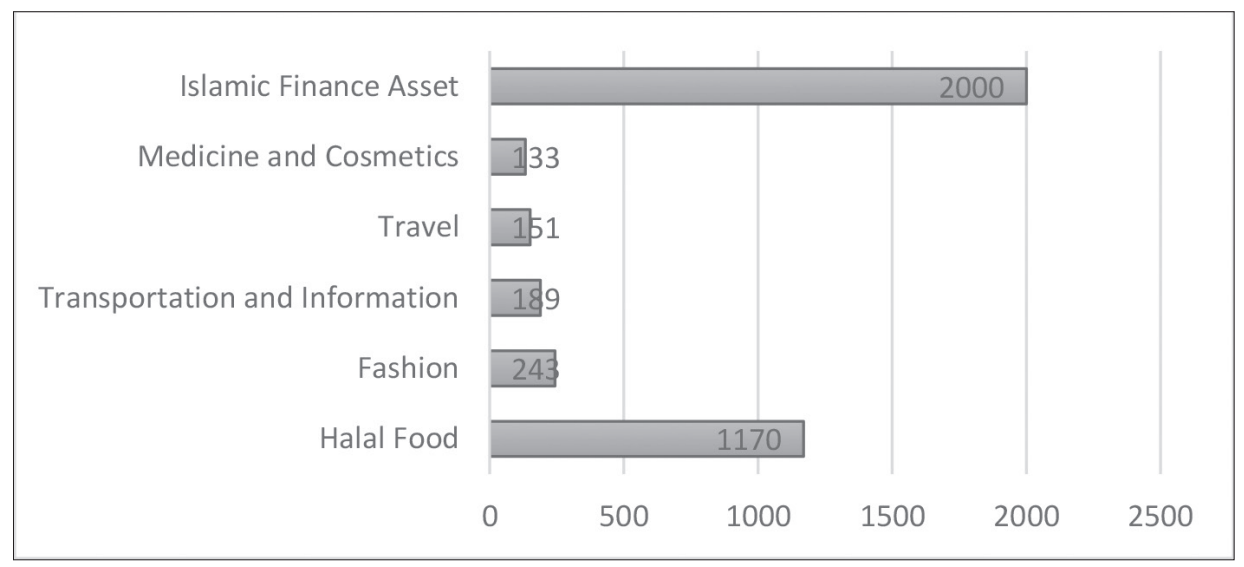

Source: Thomson Reuther (2016)

The term "halal" is a profitable business line not only among muslim countries but also non-muslim countries (Ali et al., 2017). Countries with muslims as the minority such as Thailand, South Korea, Russia, Mexico, Japan and Spain already have had halal industrial activities in their countries. This is because they have witnessed a significant growing demand for halal products. These countries consider that the halal industry is a promising business opportunity. Even Indonesia is the target of the halal product market because of the dominance of the Muslim population (IBEC-FEBUI, n.d.) ${ }^{1}$.

\footnotetext{
${ }^{1}$ http://www.ibec-febui.com/industri-halal-di-dunia-serta-potensi-dan-perkembangannya-diindonesia/ accessed on Friday, November 16, 2018
} 
Indonesia has enormous potential with regards the halal industry. Muslims as the majority of the population make Indonesia the largest consumer of halal products in the world, with economic value reaching 197 billion dollars (Thomson Reuther, 2016). With its extensive resources and supports from 207 million of muslims population out of 237 million of the total population (BPS, 2017), Indonesia should be able to be ranked first in the world halal industry market. However, at present, Indonesia is still ranked 10th in the halal industry market in the world. The first rank is held by Malaysia, which is currently developing a halal industry massively. The second rank is the United Arab Emirates and subsequently, Bahrain, Saudi Arabia, Pakistan, Oman, Kuwait, Qatar, and Jordan (Thomson Reuther, 2016).

In the Indicator of Global Islamic Economic (GIE) released by Thomson Router in 2016, Indonesia is still ranked 10th. Of all halal industrial sectors, only the sharia financial sector entered the top 10, which is ranked 9th, while for the food, fashion, pharmacy and travel sectors, Indonesia has not entered the top 10 (Thomson Reuther, 2016) even though Indonesia ranks first as the country with the highest muslim population in the world (HIDC, 2016).

The islamic financial sector is more prominent compared to other sectors in Indonesia. It is evident that the Islamic banking industry shows a high growth acceleration with an average of 40.2 percent per year in five consecutive years (20072011), while the national banking growth average is only 16.7 percent per year. In this period, the Islamic banking industry was called as 'the fastest growing industry' (Alamsyah, 2016). Although share SFI ranges from 5 percent from conventional banks, sharia financial institutions have great potential in participating the mobilization of halal industries in all sectors through financing programs and other facilities provided by SFI to halal industry players.

The potential of the islamic financial sector includes the number of sharia commercial banks, sharia business units and sharia rural banks as well as savings and loan cooperatives and Islamic finance (KSPPS) which are spread throughout Indonesia. Supported by the conducive condition of the Indonesian economy in 2011, the assessment of the Global Islamic Financial Report (GIFR) said Indonesia ranks fourth among the countries that have potential and are conducive for the development of the Islamic finance industry after Iran, Malaysia and Saudi Arabia. By looking at several aspects in calculating the index, such as the number of Islamic banks, the number of Islamic non-bank financial institutions, and the size of Islamic financial assets with the greatest weight, Indonesia is projected to be ranked first in the next few years. This optimism is in line with the rapid expansion of institutions and the accelerated growth of Islamic banking assets, added with the increasing volume of sukuk issuance (Alamsyah, 2016). 
Based on the introduction above, the opportunities and the large potential of SFI sector are expected to be a driving factor for the development of halal ecosystems and industries in Indonesia. This paper aims at discussing the role of SFI in the development of halal industries. This is to provide an overview and reveal strategies of SFI to delve the potential ecosystems and the literacy of halal industries. Also, this paper provides a broad picture, prospects for research, policies, practices and public perceptions on the relationship between the two industries in the future.

This paper uses a qualitative descriptive method as is adopted by Nisha and Iqbal (2017), with a systematic review approach to provide a broad overview of research, prospects for research, policies, practices and future public perceptions. This is because the study of integration and the role of SFI and the halal industry are empirically and conceptually still very limited at the local and global level, even though both industries have taken a long journey to make an impact on the global world. Data and information used are secondary data sourced from journals, proceedings, media information, reports and other relevant documents.

\section{Literature Review}

\section{Halal Industry}

The term of halal industry can also be applied to sharia industry or islamic industry. In a more developed term, it is often referred to as a halal industry. The concept of halal industry is the combination of the terms industry and halal. Halal is defined as all objects or activities that are permitted and allowed by the Quran and Sunnah. As for the term industry, it covers all goods and services that are processed or produced by economic activities. According to Laldin (2006), the halal industry is all industries that produce halal goods and services according to sharia. In this case, halal is a term that includes all activities that refer to all matters allowed and in accordance with Islamic law.

The command to use halal products has become one of the fundamental basis for sharia. Implicitly, the directive to use halal products can be understood as an order to eat halal food and to avoid eating the forbidden food. ${ }^{3}$ This is a clue for halal industry players to be able to implement the concept of halal into their

\footnotetext{
${ }^{2}$ Ministry of Awqaf and Islamic Affairs (2006) Maushu'ah al-Fiqhiyah. Kuwait

${ }^{3}$ As explained in al-Qur'an surah al-Baqarah: 168, 172; al-Maidah: 88; al-Anfal: 69; an-Nahl: 114; al-Mu'minun: 51; Hadith quoted from the book of Arbain by Imam Nawawi: from Abu Hurairah Rhadiyallahu Anhu, Rasulullah Shalallahu 'alaibi Wasallam said, "O people! Allah is Thayyib (Pure) and, therefore, accepts only that which is Thayyib (pure). Allah has commanded the believers as He has commanded His Messengers" Narrated by Imam Muslim.
} 
product, which becomes a necessity for muslims in particular. The goods and services produced must have benefits for human survival, and the usefulness of the products can be felt to increase the goodness of the users. The criteria for halal products must meet the requirements according to sharia; the product must be halal by halal. This means that the product is halal in the production process; put in halal storage; used halal transportation means, and halal in its presentation. All processes and stages must be clean from any possible contamination from the substance forbidden by sharia.

The development of the global halal industry—in large part—consists of banking and financial products, food and processed food, cosmetics, pharmaceuticals, media, logistics, hospitality and tourism (HIDC, 2013). With nearly 1.8 billion muslims around the world, it is this halal industry that drives businesses and consumers. According to the MIFC (2015), the global average consumer spending on food and lifestyle recorded in 2013 was the US $\$ 2$ trillion and is expected to increase to the US \$ 3.7 trillion by 2019 at a combined annual growth rate of 10.8 percent. Meanwhile, the travel sector was reported to reach the US $\$ 140$ billion in 2013 and is expected to reach the US $\$ 238$ billion by 2019 .

Halal food is one of the few categories of global food products that are at the stage of rapid growth, with more than half of the demand coming from the Asian region. Consuming halal food is important in order to fulfill the principles of Islam as well as health, hygiene and quality aspects. Meanwhile, muslims consume halal food because of their religious obligations. The concept of halal food is also acceptable for non-muslim people because of other consumption considerations, namely; health, products' origins, cleanliness, welfare and quality of animals (Wibowo and Ahmad, 2015). Recently, Brazil and Australia are known as the largest suppliers of halal meat, especially halal beef to the Middle East, while Thailand is the largest producer of halal processed food in the global halal food sector (HIDC, 2016).

Over time, the halal industry has expanded beyond the food sector to non-food products. For example, halal labels are given to cosmetic and personal care products that meet islamic regulations and do not contain substances that are prohibited by Islam. Similarly, halal medicines and health products do not contain substances that endanger the body in the long term. In this case, halal labels have been popular in some Asian countries such as Malaysia, Indonesia, Pakistan, India and Bangladesh. Thailand is currently operating the Halal Science Center, which focuses on developing standards and methods to detect prohibited substances in personal care and health products. In the fashion 
industry, seeing the potential of the development of muslim women's fashion and efforts to respect religious motives, halal fashion is applied when designing clothing for the global muslim population.

Recently, one of the popular issues is halal tourism, a rapidly expanding tourism segment. Halal tourism refers to the provision of tourism products and services that meet the needs of muslim tourists by facilitating worship needs and halal foods (Mohsin et al., 2016). In its development, halal tourism is generally associated with Umrah, Hajj and Pilgrimage, along with its development towards broader services and destinations (Battor and Ismail, 2015). The sector continues to expand by targeting broader destinations such as beaches, resorts; and launching of several specialized airlines and halal tourism websites such as Airbnb, Book halal homes, TripAdvisor and Tripfez (Reuters, 2016). In addition, the Halal Tourism Conference has emerged in an effort to promote the halal concept to support the global halal industry sector.

\section{Function and Relationship between SFI and Halal Industry}

Islamic finance refers to the method of conducting banking transactions and financial transactions that are in accordance with islamic law, also known as SFI (Dasuki, 2011). The halal economy is a joint concept between islamic finance and the halal industry. This is because the values and principles that exist in similar industries are sourced from the Quran, Hadith, Qiyas, Ijma' and Ijtihad (Rahim and Shafii, 2016). This means that the relationship between the two can be seen from the fundamental side of the application of the sharia principles.

The concept of empirical relations between SFI and halal industry can be seen from the functional side of SFI as a financial service intermediary institution. Sharia financial services are broad in the form of banking transactions such as savings, current accounts, financing and transfers, or in the form of non-banking transactions such as the islamic capital market, sukuk, mutual funds, insurancel takaful or venture. SFI as a financial institution for the halal industry sector is the intermediary for deficit and surplus units in a financial system; or as a facilitator in distributing funding and financing. Businesses and companies must use islamic finance to increase their capital, to ensure the entire production chain is in accordance with sharia. MIFC (2014) has shown a reciprocal relationship between the Halal industry and SFI, both of which can gain broader access to funding and penetration as well as greater market shares. 
Figure 2. Relationship between SFI and Halal Industri

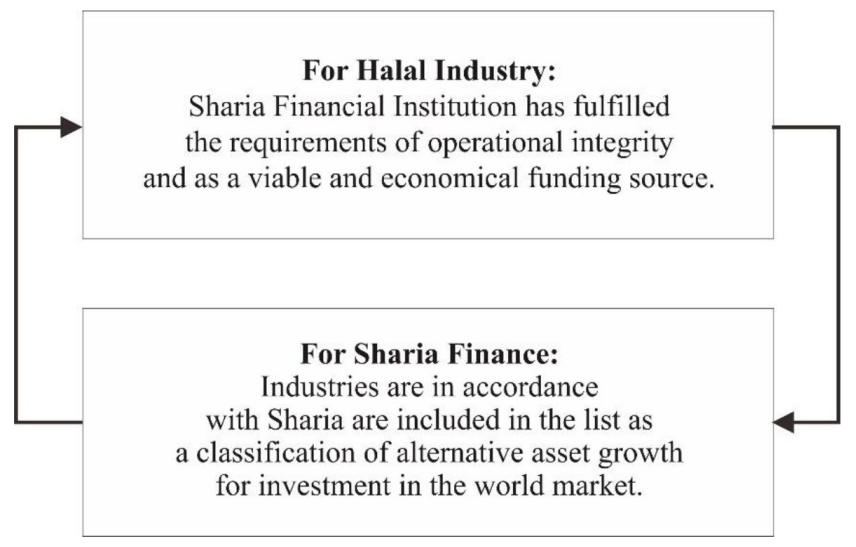

Source: WIFM, 2014

\section{Business Ecosystem in reference to Halal Ecosystems}

Business "ecosystems" refer to networks consisting of companies, suppliers, complementary companies, and customers (Adner \& Kapoor, 2010). The theory of business ecosystems comes from Moore (1993). Some of the main features of a business ecosystem are the linkages between the fate of the company and the process of competition and cooperation (Peltoniemi, 2005). Ecosystem actors include every organization that contributes to value creation for customers in the form of products or services (Iansiti and Levien, 2012). Unlike the conventional value chain view, business ecosystems offer a dynamic system picture; and not only include business value chains, but also indirect roles, such as complementary products manufacture, outsourcing companies, regulatory agencies, financial institutions, research institutions, media, universities and even competitors (Baghbadorani and Harandi, 2012).

Halal ecosystems include all business networks, institutions, and government and non-government organizations (WIFM, 2014). The halal ecosystem context refers to the halal business system, which is a form of collaboration between halal industry players to optimize the role of each sector by looking at islamic values and the development of halal industries. The halal ecosystem process is expected to improve economic values, which then lead to additional social values in the form of obligations to pay zakat, waqf, endowments, and alms.

Halal Ecosystem coverage is the integration of various sectors in the halal industry, and other actors involved. This is based on the fundamental application of sharia principles to products and services, in addition to other factors such as market 
segments that are interrelated even in different production fields. According to Velu et al. (2015), ecosystems exist when companies depend on each other to achieve common goals; ecosystems often display collaboration and competition. Similarly, the development of halal ecosystems refers to the interrelationships between halal industries in achieving common goals.

Figure 3. Business Ecosystem framework

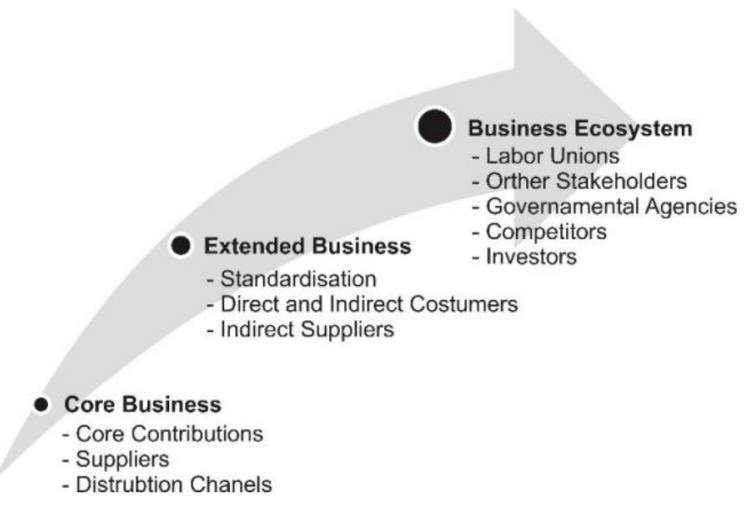

Source: Morre (1993) in Galateanu and Avasilcia (2013)

\section{Related Studies}

There have not been many studies related to the prospects and relationship between SFI, halalindustries and halal ecosystem, both on a conceptual and empirical basis. Even in a series of banking reports or annual reports of halal institutions, there are not many related studies. Although, fundamentally, both of them have the same principles and values, especially in the view of a halal economy, they appear to lack in relationships. Most of the studies are conducted in the realm of consumer behaviors, producer perceptions and experience of practitioners in both industries, but not related to the path of relations between the two industries in halal ecosystem literacy.

Conceptual research that relates to the study of the relationship between SFI and halal industry has been discussed in the WIFM report (2014) regarding the reciprocal relationship between SFI and halal industries. Then, Rahim and Syafii (2016) presents the basis of synergy between SFI, halal industry and the government, especially in Malaysia. Nisha and Iqbal (2017) examine the relationship between SFI and halal industries in the application of halal ecosystems in Bangladesh.

In an empirical study, Irfan et al. (2013) show that halal industries and SFI 
have different bodies and authorities in regulating the industry, but similarities are found in the field of research and training. Danger (2017) states that SFI can encourage SMEs in Malaysia; and islamic banking can create a positive impact on society, living environment, and a broader economy. Tungal et al., (2017) using the ARDL method, indicate that funding sources in Malaysia could help the growth of the halal industry, especially in the livestock sector. The short term result is contrary to the long-term case. This shows an insignificant relationship between the two industries. High initial costs and long production processes are the main reasons.

\section{Study and Discussion}

\section{Scenario of the Halal Industry in Indonesia}

In recent years, the halal industry has become an issue in the world. Indonesia, the country with the largest muslim population in the world, is a potential target market for the halal industry. Many from the government, researchers and the business world have begun to see the halal industry as a new market support sector in Indonesia. This potential is also supported by social factors and internal political supports in the form of government regulations in the application of halal principles. The awareness of the Indonesian muslim community in consuming halal products has reflected a deep religious literacy in the social life. Sucipto (April 15, 2009) suggests that the segment of muslim consumers in Indonesia with high concern for the halal nature of goods and services is currently growing rapidly. ${ }^{4}$

The concept of halal certification in Indonesia was first developed from halal food products. This is seen from the regulation and certification of halal food, which have developed since the issuance of Decree of the Minister of Health No 280 dated November 10, 1976 concerning Provisions on Circulation and Marking of Food Which Contains Materials Originating from Pigs. In the subsequent developments, the halal certification has been expanded to medicine and cosmetics products, marked with the establishment of the 1989 Food, Drug and Cosmetic Study Institute of Indonesian Ulama Council (LPPOM-MUI). This was followed by the issuance of Law No. 33 of 2014 concerning Guarantees of Halal Products (JPH) by the government through the Ministry of Religion. In its development, the JPH Law No. 33 of 2014 Article 4 amended the provision of halal certification from voluntary and conducted by MUI to mandatory and conducted entirely by The Halal Product Guarantee Agency (BPJPH). For the development of Islamic financial products, SFI

${ }^{4}$ https://prasetya.ub.ac.id/berita/Label-Halal-dan-Daya-Saing-Waralaba-3132-id.html accessed on Sunday, November 19, 2018 
in Indonesia was initiated by the establishment of BMT Salman at ITB, Bandung in 1980. This, then, was developed into the first sharia bank called Bank Muamalat in 1990. The provision about its operational was only accommodated in one verse of 1990 MUI National Consultative Meeting, mentioning about "banks with profit sharing systems" in Law No. 7 of 1992 without mentioning the islamic foundation ${ }^{5}$. Then in 1999, the MUI National sharia Council (DSN-MUI) was formed as a reinterpretation of the sharia guarantor of the determination and the implementation of SFI activities ${ }^{6}$. This was followed by the issuance of fatwa No. 20/2001 concerning Investment Implementation Guidelines for sharia Mutual Funds ${ }^{7}$.

Whereas for the tourism industry and information media, there is no institution that provides guarantees with regards to the sharia foundation. So, it needs encouragement to be able to provide halal guarantee certification in this particular sector as an effort to increase public trust. The Minister of Tourism, Arief Yahya (2015), mentioned that sharia-based tourism is considered to be exclusive. Consequently, the use of other terms such as islamic tourism, halal tourism, family and religious tourism is also considered inappropriate.

The practice of sharia tourism in Indonesia is yet optimal. Even if it is taken more seriously, the potential for developing sharia tourism in Indonesia is very large. Not many travel agencies have inbound trips with halal travel packages. However, there are travel packages, outbound trips, such as Umrah and hajj (Kemenpar, 2015). Based on data from the Central Bureau of Statistics and Data of the Ministry of Tourism, the number of tourists from Middle Eastern countries based on nationality from 2013-2014 is as follows: 1) Bahrain tourists amounted 98 people to 99 people (up 1.02 percent); 2) Egyptian tourists were from 675 to 733 people (up 8.59 percent); 3) Tourists from the United Arab Emirates amounted to 1,322 people to 1,428 people (up 8.02 percent); 4) Saudi Arabian tourists were from 7,522 (3.90 percent) to 7,229 people (Kemenpar, 2015).

In the institutional structure, SFI can be developed more quickly and more systematically by the supports and supervisions from policymakers, such as the Bank of Indonesia and Financial Service Authority (OJK) and DSN-MUI. The DSN-MUI supports the SFI by issuing fatwas related to its products, as well as the development of a more exogenous market share. In Indonesian, SFI haw grown

5 http://www.ojk.go.id/id/kanal/syariah/tentang-syariah/Pages/Sejarah-Perbankan-Syariah. aspx accessed on Friday, November 23, 2018

${ }^{6}$ https://dsnmui.or.id/kami/sekilas/ accessed on Friday, November 23, 2018

7 http://www.ojk.go.id/id/kanal/pasar-modal/Pages/Syariah.aspx accessed on Friday, November 23, 2018 
rapidly. In 2016, the sharia banks had total assets amounting to 356,564 billion Rupiah.

SFI Market share has developed and spread in all provinces in Indonesia. The same also happens to halal food products. According to IndonesiaTravel (2013), halal tourism has only reached 13 provinces that considered to be potential in sharia tourism sectors. These provinces are West Nusa Tenggara (NTB), Nangroe Aceh Darussalam, West Sumatra, Riau, Lampung, Banten, DKI Jakarta, West Java, Central Java, Yogyakarta, East Java, South Sulawesi, and Bali. This means that, in this case, the development of the halal tourism industry has not yet received demands from more inclusive consumers.

In the halal pharmaceutical industry, the application of halal principles has not been widely applied and, still, there has been opposition from some stakeholders in Indonesia. This is because 95 percent of the raw materials for medicine is imported from foreign countries (America, Korea, Taiwan and India). This makes it difficult to get halal certification (Ibrahim, 2017). According to Firda Chalid ${ }^{8}$, the Executive Director of the Indonesian Pharmaceutical Company (GPFI), the application of the Halal Product Assurance Law on Pharmaceutical and Medicines is very difficult, because the registration process for making drugs takes around two years. The production will need a longer period due to the halal certification process.

Consequently, access to drugs and medications is hampered by the halal certification procedures. BPOM data (2018) shows that there were, 13,638 drugs and 10,857 traditional medicines registered in BPPOM and circulating in the community. ${ }^{9}$ The drugs and medicines, which registered in LPPOM-MUI (2018), were only 302 types of drugs with halal certification. ${ }^{10}$ This is still very limited, considering the hat majority of the Indonesian population is Muslims. In this case, the halal certification institutions are expected to maximize their roles in promoting and socializing halal certification and provide easier mechanisms, especially for the pharmaceutical industry.

\footnotetext{
${ }^{8}$ http://industri.bisnis.com/read/20161006/12/589937/industri-farmasi-dan-obat-tolakmasuk-dalam-daftar-produk-wajib-halal accessed on Friday, November 30, 2018

9 http://www.pom.go.id/new/ accessed on Friday, November 30, 2018

${ }^{10} \mathrm{http}: / /$ www.halalmui.org/mui14/index.php/main/ceklogin_halal/produk_halal_masuk/1\# accessed on Friday, November 30, 2018
} 
Table 1. Summary of the Institutional Overview of the Halal Industry Sector in Indonesia

\begin{tabular}{|c|c|c|c|c|c|}
\hline $\begin{array}{l}\text { Sector of Halal } \\
\text { Industry }\end{array}$ & $\begin{array}{c}\text { Halal } \\
\text { Certificate }\end{array}$ & $\begin{array}{l}\text { Guarantor } \\
\text { Authority }\end{array}$ & Other Authority & $\begin{array}{c}\text { GIE } \\
\text { Rating }\end{array}$ & Value of Financial \\
\hline SFI & Yes & DSN-MUI & OJK, BI and LPS & 9 & $\begin{array}{l}\text { Islamic Banking Asset: IDR } \\
272.34 \text { trillion; Islamic Non- } \\
\text { bank Financial Industry Asset: } \\
\text { IDR } 54.41 \text { trillion, Islamic } \\
\text { Capital Market Capitalization } \\
\text { IDR 3,171.34 trillion (OJK, } \\
\text { 2015) }\end{array}$ \\
\hline Tourism & N/A & N/A & The Ministry of Tourism & N/A & No Data \\
\hline Food & Yes & $\begin{array}{l}\text { BPJPH \& } \\
\text { LPPOM- } \\
\text { MUI }\end{array}$ & $\begin{array}{l}\text { The Ministry of } \\
\text { Religion, The Ministry } \\
\text { of Health and MUI }\end{array}$ & N/A & No Data \\
\hline Cosmetics & Yes & $\begin{array}{l}\text { BPJPH \& } \\
\text { LPPOM- } \\
\text { MUI }\end{array}$ & $\begin{array}{l}\text { The Ministryy of } \\
\text { Religion, The Ministry } \\
\text { of Health and MUI }\end{array}$ & $\mathrm{N} / \mathrm{A}$ & No Data \\
\hline $\begin{array}{l}\text { Drug and } \\
\text { Pharmaceutical }\end{array}$ & Yes & $\begin{array}{l}\text { BPJPH \& } \\
\text { LPPOM- } \\
\text { MUI }\end{array}$ & $\begin{array}{l}\text { The Ministry of } \\
\text { Religion, The Ministry } \\
\text { of Health and MUI }\end{array}$ & N/A & No Data \\
\hline Media & N/A & N/A & $\begin{array}{l}\text { The Ministry of } \\
\text { Information }\end{array}$ & N/A & No Data \\
\hline
\end{tabular}

\section{Building Strategy for the Role of SFI in Promoting the Growth of Halal Industries in Indonesia}

In viewing the impact of encouragement from the SFI on the development of the halal industry, a multipier effect approacg is used to investigate the potency of SFI against other sectors. Moretti (2010) reveals that the multipier effect can be determined based on consumer tastes, technology, the ability of workers and income received by society. The linkage between one sector with another sector needs to be shown in the determination of the strategic sectors. The linkages between sectors can be seen from the multiplier effect of a sector that could generate activities in other sectors (Marseto, 2016). In this case, SFI is assumed to be the leading sector in the halal industry. As a result, the potential base of the SFI sector can encourage the growth and development of the halal industry. The potential of SFI is in market segmentation, the number of consumers, product roles, regulations, related authorities and asset values. This double effect is seen from the increase in the total production of the halal industry, consumer quantity, literacy, legality, certification and increasing market passion for the halal industry.

The SFI, as one of the halal industries and as an intermediary for financial services, is expected to encourage other halal industry sectors to develop literacy, 
market potential, investment, regulation and certification. In addition, SFI, through $\mathrm{OJK}$ and BI, has valid and comprehensive data sources to map the market of the islamic financial industry. It is expected that there will be more business actors that establish investment opportunities and encourage the supply of halal industries.

The role of SFI is also encouraged by the inclusion and financial literacy program. This is mentioned in the government policy, namely the 2015-2019 RPJMN and the MPSJKI by OJK and BI. It is expected that stakeholders impelement those policies to encourage literacy and education about halal certification and the optimization of halal industry literacy and the opening of new market opportunities.

SFI, as a leading sector of the halal industry, can provide booster-effects to other sectors. Moreover, SFI has comparative and competitive advantages, including in the international scale. It can be said that the SFI shows considerable growth rates, and considerable labor absorption. Also, SFI can mobilize linkages with othe halal industries and create high added values. The capability of SFI in providing multipier effects to othe halal industy sectors can be seen in the regular contributions to sectors such as education, health, disaster management, sports, cultural development, cosmetics, infrastructures, etc.

Figure 4. Sector Quotiet Influence of SFI toward Halal Industry

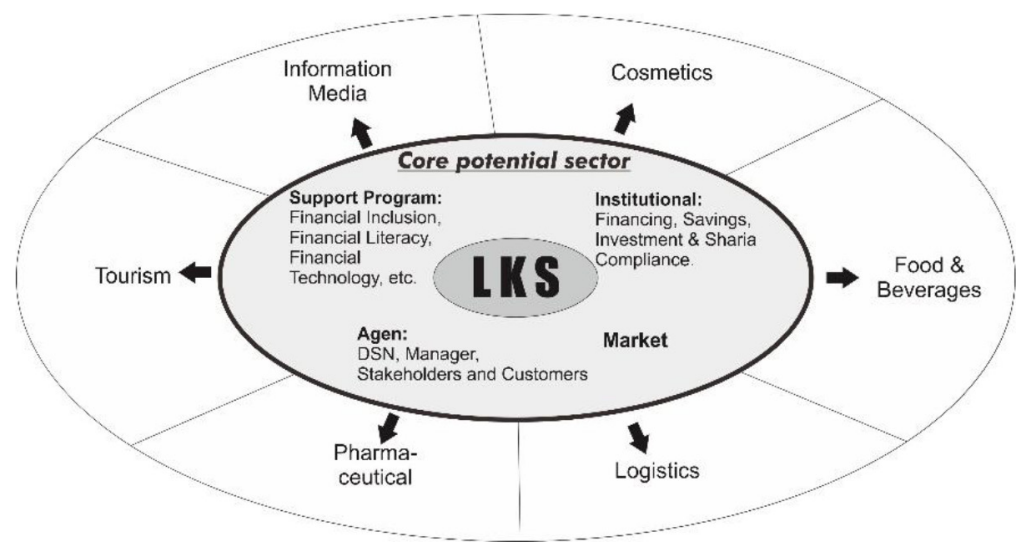

The establishment of halal ecosystems in Indonesia can provide a great opportunity for producers and marketers to develop socio-economic motives. The halal ecosystem mechanism can help companies and financial service providers to establish partnerships, synergies, and strengthen the market potential in the halal industry in Indonesia. SFI seeks to support the halal industry through the 
mechanism of savings, financing, and capitals, especially in the micro industries. Meanwhile, the halal industry supports the performance of SFI in allocating assets and liquidity in order to increase market passion and competitiveness; and providing reciprocal linkages between halal industries to create security effects among them. The involvement of policymakers is in providing regulation, certification, and standardization of the halal industries. This is to support the industries and maintain the confidence of consumers and investors.

\section{Role of the Customers Third Party Fund}

Third Party Funds (TPF), or known as public funds, are funds originated from the community as well as business entities and collected by financial institutions. The sources of third party funds are: demand deposits, savings, time deposits (Saputra et al, 2014). With regards to its function, TPF has a range of relationships for SFI to the wider community.

Efforts to optimize the of TPF on halal industry literacy become one of the effective strategies. This can be seen in the use of deposits that reflect the financial literacy of the community. According to Khairunnisa (2001), the motive of the people to place their funds in the SFI is because of the implementation of Islamic system, strong business supports (Jalaluddin, 1999) and religion (Gait and Worthington, 2009). These are important factors that influence the attitude towards islamic finance business firms. This means that TPF players have realized that knowledge and awareness of Islamic products become their basis in placing their funds in SFI. From the above perspective, the efforts to develop the literacy of halal industry can be beneficial, especially, to encourage the halal ecosystem and increase demands for halal industries.

\section{Role of Financing}

SFI plays an important role in encouraging the development of the halal industry as the distributor of funds or financing providers. In this case, SFI can meet the funding needs of halal industries for its growth and development. SFI provides funding for business sectors that meet sharia principles by implementing contracts that have been regulated in DSN-MUI fatwas.

Financing agents play an active role in ensuring to provision of funds to productive sectors according to the sharia principles. In addition, financing agents can actually provide education and encouragement in an effort to increase the capacity of the halal industries and encourage them to obtain the halal guarantee certification for their products. 


\section{Form of Synergy}

Partnerships and synergies contain a sense of cooperation, mutual trust and synergy between individuals and organizations to achieve common goals (Vasconcellos, M. and Vasconcellos, A.2009). Based on this, partnerships are related to the relationship between two or more stakeholders to combine different resources in carrying out a joint approach to achieve common goals (McQuaid, 2000; Lewis, 2000). In this context, the motive of the partnership is not formed by the idea of material benefits or coercion of registered partners, but by a common goal supported by trust between the actors (Vasconcellos, M. and Vasconcellos, A., 2009). Efforts to maximize the potential of the halal industry and halal ecosystems need synergy between institutions.

In this case, SFI alone cannot automatically encourage the potential of the halal industry. However, the synergy between institutions can encourage a more effective and efficient halal industry. Related actors include academics as researchers; the government as the regulator; relevant authorities such as BPJPH and MUI; and the community as consumers or investors. These actors can work together and synergize in facing the challenges of the halal industry in the future.

\section{Establishing a Halal Ecosystem}

Elements of the halal business ecosystem (adopting Hoover and Abell, 2009) include: 1) essential elements, namely in the form of skills, funding, cooperative systems and technical assistance; 2) important elements consist of business supports, connected markets, policies and advocacy partnerships; 3) environmental elements such as business values, attitudes and cultures, and cooperative education. Moore (1999) argues that an important aspects of ecosystems are actors (species), relationships between actors (networks), performance (health), dynamics (evolution) and strategies and behavior of actors (roles). After that, those elements are built into the concept of the halal ecosystem. The integration of halal industry actors in halal ecosystems in Indonesia involve the halal industry itself as a business actor; the government as the facilitator and the guarantor of halal entities; and infrastructure facilities. The integration, then, is resulted in networks among agents to strengthen the foundation of halal ecosystem in Indonesia. As a result, the performance of all units in the business ecosystem can be influenced by the performance of each entity.

This explanation illustrates that business ecosystem is complex adaptive systems. As Miller and Page stated, to analyze complex systems as a whole, the behavior of each component must first be understood (Miller \& Page, 2007). The success in creating and maintaining a halal ecosystem represents a viavle, growing 
and healthy business. Maintaining business ecosystem is, basically, realizing the management of an active halal industrial ecosystem, where the ecosystem is continuously monitored, including its health. Furthermore, ecosystems produce promising infrormation, with related strategies and decisions (Furthermore, ecosystems are formed towards promising information with related strategies and decisions). The health of an ecosystem is measured by productivity, endurance, and niche creation introduced by Iansity and Levien (2012). Thus, the impact of halal ecosystem can create superior products and a structured market; and enable it to compete in the global market.

Another coverage in halal ecosystems is the halal literacy process. The concept of halal literacy is a form of understanding of public and related actors about the halal industry and its related indicators such as the ability to know, consume, manage, and analyze halal products. The concept of halal literacy is based on the definition of literacy that is related to the ability of reading, writing, and understanding. According to UNESCO (2006), literacy is a process of education and enhancing skills. The concept of literacy in halal industry also includes processes and efforts in achieving knowledge and understanding of the halal industry. The process of literacy can developed along with the development of the halal industry itself, especially through the SFI sector that has large numbers of consumers. According to Fatkhurrahman (2015), Waskito (2015) and Nasution (2017), the concept of halal literacy can also increase the influence of public consumption on halal industrial products.

Figure 5. Form of Halal Ecosystem

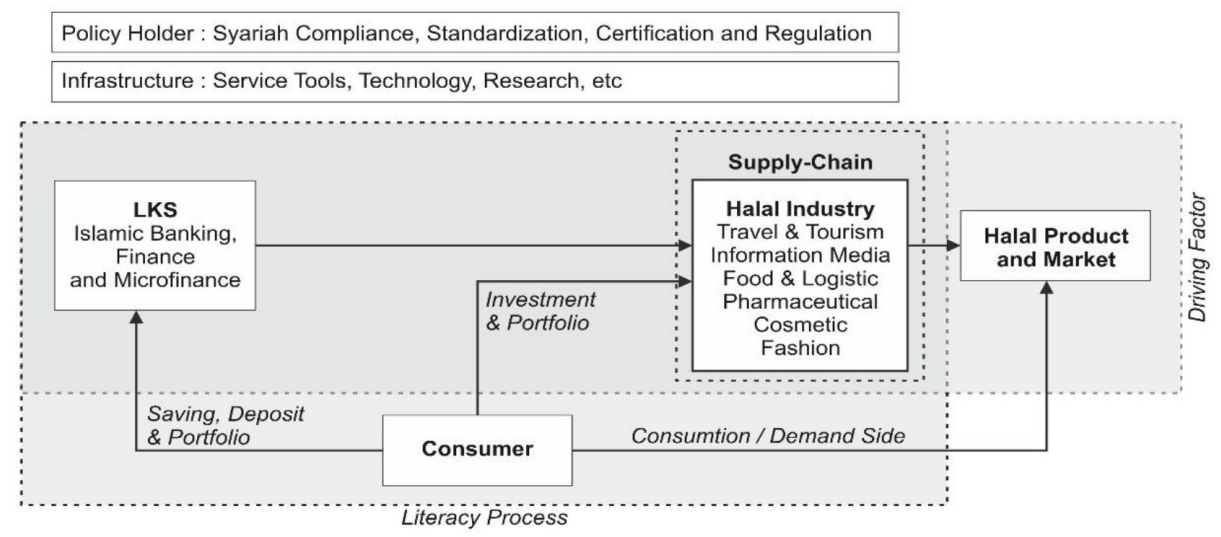




\section{Opportunities and Threats}

\section{Opportunities}

The potential of SFI in Indonesia as a global player is significant due to the large potential of muslim population, economic prospects, high investor interests, and natural resources (Alamsyah, 2012). These potential factors are expected to be explored as a driving factor for other halal industry sectors, especially in attracting investors or foreign consumers.

Indonesia, with a considerable amount of tourist destination places, only has 13 provinces as the potential destinations (Kemenpar, 2015) ${ }^{11}$, or less than 50 percent of the total provinces in Indonesia. This means that there are still big opportunities in forming a new market for halal tourism. By focusing on halal tourism, it is expected that this sector can attract local and foreign tourists, and encourage investments in the sector. OO (2012) states that the tourism sector is one of the suppliers of foreign exchange through the incoming foreign funds. This still becomes one of the focuses in the mobilization of Indonesian economy. The concept of halal tourism is expected to attract foreign tourists, especially those from the GCC countries who are predominantly muslims and have high GDP growth rates (Kemenpar, 2015).

From the market side, Indonesia is a predominantly muslim country with the largest consumption expenditure on food, with the transaction value of US USD 157.6 million. The Indonesian people have a high level of awareness of halal products. Public awareness in halal products increased by 72 percent in 2009 to 90 percent in 2010. According to research by MUI, halal certification can double the turnover (Afroniyati, 2014), Waskito (2015). The research of Pramintasari and Fatmawati (2017) shows that halal certification can increase buying interest. In this case, providing reliable guarantees can increase public trust in consuming halal products. In addition, Indonesia is expected to establish networks with other countries in supplying raw materials with halal certification. The potential cooperation between countries as outlined in MUI's Approved Foreign Halal Certification Bodies (LAFHCB) can be a driving force for the development of the halal industry in Indonesia. In addition, there is a need to expand the halal certification, not only focus on food industries, but also other sectors such as pharmaceutical and tourism.

11 https://nasional.sindonews.com/read/994208/162/13-provinsi-siap-jadi-tujuan-wisatasyariah-1430102126 accessed on Friday, November 30, 2018 


\section{Challenges}

Halal industry is now in demand by the people in the world, both muslims and non-muslims. Halal industry is one of the sectors expected to support the strength of the Indonesian economy. The worldwide demand for halal products is a challenge. The reason is, consumer preferences for consuming halal products are increasing and this is a great opportunity for various countries to maintain the competition in the global halal industry. One of the challenges to developing halal industry in Indonesia is the absence of a comprehensive regulatory framework in the halal industry fragmented and no clear mapping (Hasyim, 2011).

In terms of supply, several muslim countries still import raw materials from non-muslim countries Pandor (2011) and Hashim (2011). For example, instants noodles produced by the Indonesian companies have obtain halal certificate and have been imported to other countries. However, the raw material needed, such as wheat, is imported from Australia, Canada, United State of America, Russia, Ukraine, Kazakhstan, India, Pakistan, Brazil, and Argentina. Many products manufactured in Indonesia use wheat as the raw materials. In 2015, the noodle producers' needs for wheat reached 55 percent, while the bread and biscuits producers needs for wheat reached 22 percent and 18 percent respectively.

While the largest products with wheat raw materials are noodle producers which reached 55 percent, bread producers as much as 22 percent and 18 percent biscuits. Wheat flour needs in 2015 reached 5.7 million tons ${ }^{12}$ and in 2017 it is estimated that wheat flour needs reach 8.79 million tons ${ }^{13}$. so that it is necessary to study supply chain products imported from other countries, especially for nonmuslim countries, or countries that are not registered in LAFHCB.

There has been an imbalance in demand for halal industrial products. Currently most of the halal products come from financial and food sectors (Thomson Reuther 2016). The food sector has a market percentage of 60 percent, while the information and tourism sector has only 2 percent of the market segmentation (Elasrag, 2017). Then, there been an imbalance between the conventional capitalization market and the sharia financial sectors. Although the growth of SFI in Indonesia is very large, but the ratio of islamic banking assets is relatively small at only 5 percent of the national banks (OJK, 2017). Therefore, it is expected that halal industry actors can have access to SFI financial services

\footnotetext{
${ }^{12}$ http://www.republika.co.id/berita/ekonomi/makro/15/04/05/nmbvyl-indonesia-jadi-salahsatu-pengimpor-gandum-terbesar-dunia accessed on Friday, November 30, 2018

${ }^{13} \mathrm{http}$ ///industri.kontan.co.id/news/impor-gandum-2017-diprediksi-tembus-879-juta-ton accessed on Friday, November 30, 2018
} 
to create causal effects for both the SFI and halal industries, as well as increasing the role of halal industry agents in an effort improve halal industry products and industrial competitiveness both domestically and globally.

In terms of the standardization and legality, not all halalproducts have obtained halal licenses from the authorized institutions. Currently, the certification provided by the certification agencies is limited to SFI, food, cosmetics, pharmaceutical industries. For the tourism and information media industries, on the other hand, there has been no institution available as halal certificate providers. This is a challenge for Indonesia to formulate the regulations so that all halal industry sectors have legal and accountable recognition institutions.

\section{Conclusion}

There is still a space for adjustment in the integration between the SFI and halal industries as stated by Muhamed et al. (2014). Furthermore, there is a need to urge stakeholders from each industry sector to be able to work together in opening up available potentials. In relation to consumer factors and a large market share, SFI is expected to encourage the productivity of the halal industry and the community literacy regarding the halal industry, and encourage a more structured integrated halal ecosystem.

The business ecosystem concept, as a business innovation, plays roles in increasing the innovation and market competitiveness (Velu et al., 2015). The implementation of halal industry ecosystem, which integrates various agents, is one of the concrete steps in increasing the potential and literacy of the halal industry in Indonesia.

The huge potential of halal industry markets still needs to be developed and supported by related stakeholders. There have been still inequalities between the products, demand, market, institutional structures within the halal industries. Related to the halal guarantee, the halal certification is still focused on products such as food, medicines, cosmetics and SFI, while tourism and information media related products remain untouched. On the market side, SFI and food industries have dominated the halal industry and support the development of the halal industry. So, it is necessary to encourage the development of other sectors apart from those two. This can be done by providing specific guidelines regarding the development of the halal industry to become a reference for relevant agencies. 


\section{References}

Adner, Ron. \& Rahul Kapoor. 2010. "Value Creation in Innovation Ecosystems: How the Structure of Technological Interdependence Affects Firm Performance in New Technology Generations." Strategic Management Journal 31(3): 306-333.

Afroniyati, Lies. 2014. "Analisis Ekonomi Politik Sertifikasi Halal oleh Majelis Ulama Indonesia." Jurnal Kebijakan dan Administrasi Publik 18(1): 37-52.

Alamsyah, H. 2012. "Perkembangan dan Prospek Perbankan Syariah di Indonesia: Tantangan dalam Menyokong MEA 2015." Presented at Ceramah Ilmiah Ikatan Ahli Ekonomi Islam (IAEI), $8^{\text {th }}$ IAEI Anniversary, Bank Indonesia, April 13, 2012.

Ali, Afzaal. Guo Xiaoling, Mehkar Sherwani \& Adnan Ali. 2017. "Factors Affecting Halal Meat Purchase Intention: Evidence from International Muslim Students in China." British Food Journal 119(3): 527-541.

Badan Pengawasan Obat dan Makanan. (n.d.). Statistik Produk yang Mendapat Persetujuan Izin Edar. Retrieved November 30, 2018. from https://www. pom.go.id/new/

Baghbadorani, Milad Fathi \& Amirpouyan Harandi. 2012. "A Conceptual Model for Business Ecosystem and Implications for Future Research." IPEDR 52(7): 82-86. Retreived from DOI: 10.7763/IPEDR. 2012. V52. 17.

Battour, M., \& Ismail, M. N. 2015. "Halal Tourism: Concepts, Practices, Challenges and Future." Tourism Management Perspectives 19(B): 150-154.

Badan Pusat Statistik. 2017. Statistik Politik Indonesia 2017. Jakarta: Badan Pusat Statistik.

DSN-MUI (n.d.) Sekilas tentang DSN MUI. Retrieved November 23, 2018. from https://dsnmui.or.id/kami/sekilas/

Dusuki, Asyraf Wajdi. 2011. "Role of Islamic Finance in Supporting the Halal Industry and its Services." Proceeding at The First Gulf Conference on Halal Industry and its Services.

Fatkhurohman. 2015. "Pengaruh Pemahaman Label Halal dan Faktor Sosial terhadap Niat Pembelian Produk Kemasan Berlabel Halal: Studi pada Santri Mahasiswa Pondok Pesantren Al-Barokah.” Bachelor Thesis. Universitas Negeri Yogyakarta, Indonesia. Retrieved from https://eprints.uny. ac.id/24694/

Galateanu, Elena \& Silvia Avasilcai, S. 2013. "Business Ecosystem "Reliability"." Procedia - Social and Behavioral Sciences 124(20 March): 312 - 321. 
Halal Industry Development Corporation. 2013. Industry sectors. Retrieved from http://www.hdcglobal.com/publisher/bhi_industry_sectors.

Halal Industry Development Corporation. 2016. Future Directions of Halal in Malaysia: Opportunities for Trade and Investment. HIDC: Malaysia.

Halal MUI. (n.d.). Pencarian Produk Halal: Obat-Obatan. Retrieved November 30, 2018. from http://www.halalmui.org/mui14/index.php/main/ceklogin_ halal/produk_halal_masuk/1\#

Hashim, Dzulkifly Mat. 2011. Chemical Status: Pharmaceutical Ingredients. Proceeding at The First Gulf Conference on Halal Industry and its Services.

Iansiti, Marco \& Roy Levien. 2012. Keystones and Dominators: Framing Operating and Technology Strategy in a Business Ecosystem. Working paper / Division of Research, Harvard Business School.

IBEC-FEBUI (n.d.) Industri Halal di Dunia serta Potensi dan Perkembangannya di Indonesia. Retrieved November 16, 2018. from http://www.ibec-febui.com/ industri-halal-di-dunia-serta-potensi-dan-perkembangannya-di-indonesia/

Ibrahim, Slamet. 2017. "Kesiapan Industri Farmasi dan Implementasi UU JPH pada Produk Farmasi." Presented at Pertemuan Ilmiah Tahunan (PIT) Ikatan Apoteker Indonesia. September 6-7, 2017.

Industri-Bisnis. (October 06, 2016). Industri Farmasi dan Obat Tolak Masuk dalam Daftar Produk Wajib Halal. Retrieved November 30, 2018. from https:// industri.bisnis.com/read/20161006/12/589937/industri-farmasi-dan-obattolak-masuk-dalam-daftar-produk-wajib-halal.

Irfan, I. S., M. Daud Awang \& Suhaimi Ab. Rahman. 2013. "The Concept of Halal Economy: An Initiative to Integrate the Halal Products Industry and Islamic Banking and Finance" Presented at the 5th Islamic Economy System Conference, Kuala Lumpur, Malaysia, 2013.

Kementrian Pariwisata. 2015. Laporan akhir kajian pengembangan wisata syariah. Jakarta: Asisten Deputi Penelitian dan Pengembangan Kebijakan Kepariwisataan Deputi Bidang Pengembangan Kelembagaan Kepariwisataan, Kementerian Pariwisata. Indonesia.

Khairunnisa. 2001. "Preferensi Masyarakat Terhadap Bank Syariah (Studi Kasus Bank Muammalat Indonesia dan Bank BNI Syariah)." Unpublished Thesis. Universitas Gadjah Mada, Yogyakarta, Indonesia.

Kontan. (February 27, 2017). Impor Gandum 2017 Diprediksi Tembus 8,79 Juta Ton. Retrieved November 30, 2018 from https://industri.kontan.co.id/news/ impor-gandum-2017-diprediksi-tembus-879-juta-ton 
Laldin, Muhammad Akram. 2006. Islamic Law: An Introduction. Kuala Lumpur: International Islamic University Malaysia.

Lewis, D. 2000. Building 'Active' Partnership in Aid-Recipient Countries: Lessons from a Rural Development Project in Bangladesh, in Osborne, S. P. (org.). Public-Private Partnerships: Theory and Practice in International Perspective. London: Routledge.

Marseto. 2016. Model Pemetaan Potensi Sektor Ekonomi di Kabupaten Madiun. Surabaya: Digital Repository UPN Veteran Jawa Timur.

Ministry of Awqaf and Islamic Affairs. 2006. Mausu'ah al-Fiqhiyah. Kuwait: Ministry of Awqaf and Islamic Affairs.

McQuaid, Ronald W. 2000. The Theory of Partnership: Why Have Partnerships? In Public-Private Partnerships: Theory and Practice in International Perspective, ed. Stephen P. Osborne. London: Routledge.

MIFC. 2015. Halal Ecosystem: Prospects for Global Growth. Malaysia: Malaysia International Islamic Financial Centre.

Mohsin, Asad, Noriah Ramli, Bader Abdulaziz Alkhulayfi. 2016. "Halal Tourism: Emerging Opportunities.” Tourism Management Perspectives 19: 137-143.

Moore, James F., 1993. "Predators and Prey: A New Ecology of Competition." Harvard Business Review, 71: 75-75.

Moore, James F. 1999. The Death of Competition: Leadership and Strategy in the Age of Business Ecosystems. Harper Business. Hoboken N.J: Wiley.

Muhamed, Nurul A., Natasha Ramli, Sumaiyah Aziz \& Nor Yaakub. 2014. "Integrating Islamic Financing and Halal Industry: A Survey on Current Practices of the Selected Malaysian Authority Bodies." Asian Social Science 10(17): 120-126.

Nasution, N. A. 2017. "Analisis Pengaruh Pemahaman Label Halal dan Faktor Sosial terhadap Niat Beli Produk Makanan dalam Kemasan Berlabel Halal: Studi pada Santri Pondok Pesantren Krapyak." Bachelor Thesis, Universitas Muhammadiyah Yogyakarta, Indonesia. Retrieved from http://digilib.uinsuka.ac.id/24934/

Nisha, Nabila \& Mehree Iqbal. 2017. "Halal Ecosystem: Prospect for Growth in Bangladesh." International Journal of Business and Society 18: 205-222.

Otoritas Jasa Keuangan. 2015. Roadmap Pasar Modal Syariah 2015-2019. Jakarta: Direktorat Pasar Modal Syariah Otoritas Jasa Keuangan.

Otoritas Jasa Keuangan. 2017. Statistik Perbankan Indonesia - Desember 2017. Jakarta: Otoritas Jasa Keuangan. 
Otoritas Jasa Keuangan. (n.d.). Pasar Modal Syariah. Retrieved November 23, 2018. from https://www. ojk.go.id/id/kanal/pasar-modal/Pages/Syariah.aspx

Otoritas Jasa Keuangan. (n.d.). Sejarah Perbankan Syariah. Retrieved November 23, 2018. from https:// www.ojk.go.id/id/kanal/syariah/tentang-syariah/Pages/ Sejarah-Perbankan- Syariah.aspx

Pandor, Yusuf. 2011. Global Challenges in Halal Supply Chains. Proceeding of The First Gulf Conference on Halal Industry and its Services

Peltoniemi, M., 2006. "Preliminary Theoretical Framework for the Study of Business Ecosystems." Emergence: Complexity and Organization 8(1): 10-19.

Pramintasari, T. R \& I. Fatmawati. 2017. "Pengaruh Keyakinan Religius, Peran Sertifikasi Halal, Paparan Informasi dan Alasan Kesehatan terhadap Kesadaran Masyarakat pada Produk Makanan Halal." Jurnal Manajemen Bisnis 8(1): 1-33.

Rahim, Norafni Farlina, Zurina Shafi'i. 2016. The Nexus of Islamic Finance and Halal Industry: Bridging A Gap in Halal Economy. Proceeding in 4th International Forum of Sfax on Islamic Financial Engineering: Shariah Complinace, Profitability and Development Requirement, 27-28 April, Sfax Tunisia.

Republika (April 5, 2015) Indonesia Jadi Salah Satu Pengimpor Gandum Terbesar Dunia. Retrieved November 30, 2018 from https:/www.republika. co.id/ berita/ekonomi/makro/15/04/05/nmbvyl-indonesia-jadi-salah-satupengimpor-gandum-terbesar-dunia

Saputra, I. Putu Eka, Wayan Cipta, \& Ni Nyoman Yulianthini. 2014. Pengaruh Dana Pihak Ketiga (DPK), Penyaluran Kredit, dan Kredit Bermasalah terhadap Profitabilitas pada Lembaga Perkreditan Desa (LPD) Kecamatan Karangasem, e-Journal Bisma, Universitas Pendidikan Ganesha Jurusan Manajemen, 2.

Sindo (April 27, 2015) 13 Provinsi Siap Jadi Tujuan Wisata Syariah. Retrieved November 30, 2018. from https://nasional.sindonews.com/ $\mathrm{read} / 994208 / 162 / 13$-provinsi-siap-jadi-tujuan-wisata-syariah-1430102126

Sucipto (April 15, 2009) Label Halal dan Daya Saing Waralaba. Retrieved November 19, 2018. from https://prasetya.ub.ac.id/berita/Label-Halal-dan- DayaSaing-Waralaba-3132-id.html

Thomson Reuters. 2016. State of the Global Islamic Economy Report 2015/16. New York: Thomson Reuters.

Thomson Reuters. 2017. State of The Global Islamic Economy Report 2016/17. New York: Thomson Reuters. 
Tungal. Zainab, Ahmad Aizuddin Hamzah, Mohd Fahmi Ghazali, Nur Shahirah Azman. 2017. "Impact of Islamic Financing Sources on Halal Products: In a Case of Livestock Industry in Malaysia" Presented in International Conference on Applied Economics and Policy, 21-22 August 2017, University of Malaya, Kuala Lumpur, Malaysia.

UNESCO. 2006. Education for All Global Monitoring Report 2006. France: UNESCO.

Vasconcellos, Mario \& Ana Maria Vasconcellosn A. M. 2009. "Partnership, Empowerment and Local Development." Interaçôes, Campo Grande 10(2): 133-148.

World's Islamic Finance Market Marketplace. 2014. The Halal Economy: Huge Potential for Islamic Finance. Malaysia: WIFM.

Velu, Chander, Andi Smart \& M. Phillips. 2015. "The Imperative for Business Model Innovation: A Research and Practice Perspective." Paper Presented at Business Model Innovation Workshop, the Institute for Manufacturing (IfM), University of Cambridge.

Waskito, Danang. 2015. "Pengaruh Sertifikasi Halal, Kesadaran Halal dan Bahan Makanan terhadap Minat Beli Produk Makanan Halal: Studi pada Mahasiswa Muslim di Yogyakarta." Bachelor Thesis, Universitas Negeri Yogyakarta, Indonesia. Retrieved from https://eprints.uny.ac.id/29163/

Wibowo, Mas Wahyu \& Fauziah Sheikh Ahmad. 2016. "Non-Muslim Consumers' Halal Food Product Acceptance Model." Procedia Economics and Finance, 37: $276-283$

Yahaya, E. A. H. 2017. "Islamic Finance-Potential Growth Areas and Challenges." Paper presented at 14th Kuala Lumpur Islamic Finance Forum (KLIFF) 2017, Kuala Lumpur, October 3, 2017.

Yusuf, Eddy \& Mohd Shukri Ab. Yajid. 2016. "Halal Pharmaceuticals and Cosmeceuticals from the Perspective of Higher Education." Asian Journal of Pharmaceutical Sciences, 11: 18-19. 